\title{
Clinical characteristics of chronic bronchitic, emphysematous and ACOS phenotypes in COPD patients with frequent exacerbations
}

This article was published in the following Dove Press journal:

International Journal of COPD

18 July 2017

Number of times this article has been viewed

\section{Yusheng Cheng* \\ Xiongwen Tu* \\ Linlin Pan \\ Shuai Lu \\ Ming Xing \\ Linlin Li \\ Xingwu Chen}

Department of Respiratory Medicine, Yijishan Hospital of Wannan Medical

College, Wuhu, People's Republic of China

*These authors contributed equally to this work
Correspondence: Xingwu Chen

Department of Respiratory Medicine, Yijishan Hospital of Wannan Medical

College, 2 Zeshan West Road, Jinghu,

Wuhu, Anhui, 24I00I, People's

Republic of China

Tel +865535739229

Email yjscxw2006@I26.com
Purpose: Chronic bronchitis (CB), emphysematous (EM) and asthma-chronic obstructive pulmonary disease (COPD) overlap syndrome (ACOS) phenotypes in COPD are well recognized. This study aimed to investigate distinguishing characteristics of these phenotypes in COPD patients with frequent exacerbations (FE).

Patients and methods: A retrospective study was carried out. COPD patients with acute exacerbations were consecutively reviewed from November 2015 to October 2016. Patients were divided into FE and infrequent exacerbations (iFE) subgroups.

Results: A total of 142 eligible COPD subjects were reviewed. In the CB phenotype subgroup, age, body mass index, forced expiratory volume in 1 second $\left(\mathrm{FEV}_{1}\right) \%$ predicted, $\mathrm{COPD}$ assessment test (CAT), modified Medical Research Council breathlessness measurement (mMRC) dyspnea scale, emphysema scores and arterial carbon dioxide pressure $\left(\mathrm{PaCO}_{2}\right)$ were significantly different in subjects with FE when compared to those in subjects with iFE of CB. In the EM phenotype subgroup, age, CAT, mMRC scores and history of COPD were different in subjects with FE when compared to those in CB subjects with iFE. Multivariate analysis indicated that $\mathrm{FEV}_{1} \%$ predicted (odds ratio $[\mathrm{OR}]=0.90, P=0.04$ ) and $\mathrm{PaCO}_{2}(\mathrm{OR}=1.22, P=0.02$ ) were independent risk factors for $\mathrm{FE}$ in $\mathrm{COPD}$ with $\mathrm{CB}$ phenotype, and $\mathrm{CAT}$ ( $\mathrm{OR}=2.601, P=0.001$ ) was the independent risk factor for FE in COPD with EM phenotype. No significant differences in characteristics were observed in ACOS phenotype subgroups with FE or iFE.

Conclusion: In CB or EM phenotypes, COPD patients with FE present several differential clinical characteristics compared to patients with iFE, while the characteristics of ACOS phenotype in patients with FE need more investigation.

Keywords: chronic bronchitis, emphysema, ACOS, COPD, frequent exacerbations

\section{Introduction}

Chronic obstructive pulmonary disease (COPD) is a common and heterogeneous respiratory disease involving different pathophysiological changes and is a major cause of morbidity and mortality worldwide. ${ }^{1}$ Incompletely reversible airflow obstruction, the hallmark of COPD, presents as diverse clinical manifestations. Clinical phenotypes of COPD are differentiated by severity of systemic inflammation, quality of life, the degree of airway obstruction and the response of available medications. ${ }^{2}$ Chronic bronchitis (CB), emphysematous (EM) and asthma-COPD overlap syndrome (ACOS) are the three generally accepted clinical phenotypes. ${ }^{3-6}$ In an observational and multicenter study, it was reported that CB accounted for $44.7 \%$ of COPD patients, EM was $43.2 \%$ and ACOS was only $12.1 \% .{ }^{6} \mathrm{COPD}$ patients with $\mathrm{CB}$ showed greater chronic dyspnea and activity restriction than patients without $\mathrm{CB} .{ }^{7}$ Compared to $\mathrm{CB}$ or ACOS phenotype, 
COPD patients with EM phenotype present with poorer pulmonary function and greater dyspnea. ${ }^{6}$ Notably, COPD patients with ACOS phenotype suffer more from obesity and atopic diseases, compared to COPD patients without ACOS phenotype. ${ }^{8}$ However, a subgroup of COPD patients experience frequent exacerbations (FE), which was clearly described in the ECLIPSE (Evaluation of COPD Longitudinally to Identify Predictive Surrogate Endpoints) study and was associated with accelerated deterioration of lung function, high economic burden and increased mortality. ${ }^{9,10}$

Around $16 \%$ of FE patients are of the EM phenotype. ${ }^{11}$ COPD patients with FE in the CB phenotype are the only patient group that benefits from treatment with phosphodiesterase-4 inhibitors. ${ }^{12}$ The ACOS phenotype is reported to be a predictor for FE in patients with COPD. ${ }^{13}$ Only limited prior work has been undertaken to evaluate these typical phenotypes in COPD patients with FE. The purpose of this study was to investigate differential characteristics of these phenotypes in COPD patients with FE, compared to those patients with infrequent exacerbations (iFE).

\section{Patients and methods}

\section{Study subjects}

This was a retrospective study which was approved by the Institutional Ethics Committee of Wan Nan Medical College. Due to the retrospective nature of the study all patient data were strictly confidential and the committee waived the need for written informed consent from the subjects. COPD subjects with acute exacerbations, admitted to the Department of Respiratory Medicine, Yijishan Hospital of Wannan Medical College, were reviewed from November 2015 to October 2016. Patients with CB, EM or ACOS phenotype were included. Patients with comorbidities of pulmonary tuberculosis, pulmonary fibrosis, bronchiectasis, lung cancer, pulmonary embolism or other organ failures were excluded. The definition of acute exacerbations of COPD followed the guideline of Global Initiative for Chronic Obstructive Lung Disease (GOLD). FE was defined by the presence of at least two exacerbations (an increase in, or new onset of, $\geq 2$ respiratory symptoms, such as cough, sputum, dyspnea, wheezing and chest tightness, with $\geq 1$ symptom lasting for $\geq 3$ days and requiring treatment with antibiotics and/or systemic steroids or hospitalization) in the previous year and separated by at least 4 weeks (or 6 weeks from the previous exacerbation that did not receive treatment). Others were categorized into the iFE group. ${ }^{14}$ The definition of $\mathrm{CB}$ was chronic phlegm alone for most days, 3 months a year, for 2 years. EM was defined as no chronic cough and sputum, but having typical clinical and radiologic manifestations of EM. The ACOS definition was based on dyspnea at rest and wheezing episodes, with post-bronchodilator forced expiratory volume in 1 second $\left(\mathrm{FEV}_{1}\right)$ /forced vital capacity (FVC) $<0.7$ and bronchodilator responsiveness (increase in $\mathrm{FEV}_{1}$ $\geq 12 \%$ and $\geq 200 \mathrm{~mL}$ increase over baseline value). ${ }^{15}$

\section{Clinical parameters}

All clinical parameters were collected and appraised during 24 hours after patients' admission. Demographic and clinical data including age, gender, body mass index (BMI), smoking index and medical history were collected from medical databases in our hospital. Pulmonary function tests and results of routine hematological examination (white blood cell counts, neutrophils, neutrophil-to-lymphocyte ratio [NLR], C-reactive protein and arterial blood gas) were also collected. The COPD assessment test (CAT) and the modified Medical Research Council breathlessness measurement (mMRC) dyspnea scale were assessed as previously described. Thoracic high-resolution computed tomography (HRCT) was performed with a Philips Brilliance 16-slice spiral CT scanner. Sequential scanning was performed continuously from the apex to the diaphragm at maximal inspiration with a slice thickness of $1 \mathrm{~mm}$ and a layer distance of $10 \mathrm{~mm}$. HRCT images were visualized on coronal and sagittal planes to assess the heterogeneity of emphysema by two independent pulmonologists blinded to the patients' clinical information. The distribution of emphysema was qualitatively assessed by a modified 5-point visual scoring system as follows: a score of 1 indicated obvious predominance of emphysema in upper lung; 2, somewhat predominance of emphysema in upper lung; 3 , equal extent of emphysema in upper and lower lung; 4, somewhat predominance of emphysema in lower lung and 5, obvious predominance of emphysema in lower lung. ${ }^{16}$ A simplified CT scoring system was used to assess bronchial wall thickening for each patient: $0=$ absent; $1=$ mild (air wall thickness equal to adjacent vessel); $2=$ moderate (air wall thickening $>$ adjacent vessel, but $\leq 2 \times$ the diameter of adjacent vessel), and $3=$ severe (airway wall thickening $>2 \times$ diameter of adjacent vessel). ${ }^{17}$

\section{Statistical analysis}

Data were expressed as mean \pm standard deviation or number (n). Categorical variables were compared between groups using chi-square testing. Continuous variables were evaluated by Student's $t$-test. Multivariate analysis was used to assess risk factors for FE in different phenotypes. Odds ratios (OR) and 95\% CIs were presented. A $P$-value $<0.05$ 
was considered statistically significant. Statistical analyses were done using SPSS 17.0.

\section{Results}

\section{Baseline characteristics of COPD patients with FE or iFE}

A total of 142 eligible COPD subjects were reviewed: 60 subjects were categorized as FE and 82 with iFE. As shown in Table 1 - which summarizes clinical data without subphenotyping - subjects with FE were on average substantially older than those with iFE $(P=0.001)$. Subjects with FE had longer history of COPD than subjects with iFE $(P=0.001)$. Smoking index, pulmonary function testing, CAT score, mMRC, bronchial thickening score and $\mathrm{PaCO}_{2}$ in subjects with FE shared significant differences with those in subjects with iFE. However, the proportion of $\mathrm{CB}$,

Table I Characteristics of all COPD patients with FE or iFE

\begin{tabular}{|c|c|c|c|}
\hline Variables & $\begin{array}{l}\text { Subjects } \\
\text { with FE }\end{array}$ & $\begin{array}{l}\text { Subjects } \\
\text { with iFE }\end{array}$ & $P$-value \\
\hline Total subjects $(\mathrm{N})$ & 60 & 82 & \\
\hline Male (n) & 47 & 62 & $0.84 I$ \\
\hline Age (years) & $72.1 \pm 8.24$ & $66.72 \pm 10.97$ & 0.001 \\
\hline History of COPD (years) & $15.43 \pm 9.35$ & $10.4 \pm 7.47$ & 0.001 \\
\hline Smoking index (pack $\times$ years) & $53.46 \pm 52.95$ & $38.31 \pm 21.45$ & 0.040 \\
\hline BMI $\left(\mathrm{kg} / \mathrm{m}^{2}\right)$ & $20.5 I \pm 4.19$ & $21.34 \pm 3.07$ & 0.192 \\
\hline $\mathrm{FEV}_{1}(\%$ predicted $)$ & $42.22 \pm 17.19$ & $48.93 \pm 16.91$ & 0.022 \\
\hline $\mathrm{FEV}_{\mathrm{I}} / \mathrm{FVC}(\%)$ & $50.72 \pm 10.7$ & $57.74 \pm 9.31$ & 0.000 \\
\hline CAT score & $29.53 \pm 3.9$ & $23.77 \pm 6.26$ & 0.000 \\
\hline mMRC & $3.08 \pm 0.74$ & $2.13 \pm 0.94$ & 0.000 \\
\hline Emphysema score & $2.3 \pm 1.43$ & $2.02 \pm 1.52$ & 0.275 \\
\hline Bronchial thickening score & $1.25 \pm 0.68$ & $0.95 \pm 0.7$ & 0.012 \\
\hline Leukocyte $\left(\times 10^{9}\right)$ & $7.48 \pm 2.79$ & $7.87 \pm 3.09$ & 0.449 \\
\hline NLR & $8.98 \pm \mid 2.61$ & $5.72 \pm 4.7$ & 0.079 \\
\hline CRP (mg/L) & $56.35 \pm 67.4$ & $44.3 \pm 67.31$ & 0.429 \\
\hline $\mathrm{pH}$ value & $7.4 I \pm 0.05$ & $7.42 \pm 0.04$ & 0.079 \\
\hline $\mathrm{PaO}_{2}(\mathrm{mmHg})$ & $86.79 \pm 27.35$ & $78.35 \pm 20.34$ & 0.070 \\
\hline $\mathrm{PaCO}_{2}(\mathrm{mmHg})$ & $45.69 \pm 12.4$ & $41.19 \pm 8.88$ & 0.040 \\
\hline Phenotypes of COPD & & & 0.119 \\
\hline Chronic bronchitis (n) & 30 & 27 & \\
\hline Emphysema (n) & 20 & 38 & \\
\hline $\operatorname{AcOS}(n)$ & 10 & 17 & \\
\hline \multicolumn{4}{|l|}{ Medical history } \\
\hline Systemic hypertension (n) & 16 & 13 & 0.141 \\
\hline Coronary heart disease $(n)$ & 7 & 2 & 0.036 \\
\hline Diabetes mellitus ( $n$ ) & 9 & 2 & 0.009 \\
\hline
\end{tabular}

Notes: Data are presented as mean \pm standard deviation, number $(n)$, or percentage. $P$-value $<0.05$ was considered statistically significant: data shown in bold. Abbreviations: ACOS, asthma-COPD overlap syndrome; BMI, body mass index; CAT, COPD assessment test; COPD, chronic obstructive pulmonary disease; CRP, $\mathrm{C}$-reactive protein; $\mathrm{FE}$, frequent exacerbations; $\mathrm{FEV}$, forced expiratory volume in I second; FEV, /FVC, the ratio of FEV, and forced vital capacity; iFE, infrequent exacerbations; mMRC, modified British Medical Research Council breathlessness measurement; $\mathrm{NLR}$, neutrophil lymphocyte ratio in whole blood; $\mathrm{PaCO}_{2}$, arterial carbon dioxide pressure; $\mathrm{PaO}_{2}$, arterial oxygen pressure.
Table 2 Characteristics of the chronic bronchitis phenotype in COPD patients with FE vs iFE

\begin{tabular}{|c|c|c|c|}
\hline Variables & $\begin{array}{l}\text { Subjects } \\
\text { with FE }\end{array}$ & $\begin{array}{l}\text { Subjects } \\
\text { with ifE }\end{array}$ & $P$-value \\
\hline Total subjects $(\mathrm{N})$ & 30 & 27 & \\
\hline Male (n) & 24 & 17 & 0.238 \\
\hline Age (years) & $73 \pm 6.4$ & $64.37 \pm 12.5$ & 0.003 \\
\hline History of COPD (years) & $14.17 \pm 9.5$ & $10.44 \pm 8.45$ & 0.124 \\
\hline Smoking (pack $\times$ years) & $64.05 \pm 70.1$ & $43.33 \pm 28.77$ & 0.158 \\
\hline BMI $\left(\mathrm{kg} / \mathrm{m}^{2}\right)$ & $19.82 \pm 3.62$ & $22.07 \pm 3.11$ & 0.016 \\
\hline $\mathrm{FEV}_{1}$ (\% predicted) & $40 \pm 13.61$ & $51.74 \pm 16.13$ & 0.004 \\
\hline $\mathrm{FEV}_{1} / \mathrm{FVC}(\%)$ & $51.17 \pm 10.78$ & $57.47 \pm 10.18$ & 0.028 \\
\hline CAT score & $29.4 \pm 3.94$ & $23.4 I \pm 6.98$ & 0.000 \\
\hline $\mathrm{mMRC}$ & $3.1 \pm 0.7 I I$ & $2.15 \pm 1.1$ & 0.000 \\
\hline Emphysema score & $1.97 \pm 1.56$ & $0.63 \pm 1.15$ & 0.001 \\
\hline Bronchial thickening score & $1.43 \pm 0.68$ & $1.19 \pm 0.4$ & 0.095 \\
\hline Leukocytes $\left(\times 10^{9}\right)$ & $8.29 \pm 3.14$ & $8.7 \pm 3.78$ & 0.656 \\
\hline NLR & II. $.42 \pm 6.35$ & $17.03 \pm 5.3$ & 0.144 \\
\hline $\mathrm{CRP}(\mathrm{mg} / \mathrm{L})$ & $53.38 \pm 54.72$ & $42.26 \pm 54.89$ & 0.557 \\
\hline $\mathrm{pH}$ value & $7.4 I \pm 0.05$ & $7.43 \pm 0.05$ & 0.272 \\
\hline $\mathrm{PaO}_{2}(\mathrm{mmHg})$ & $83.23 \pm 30.75$ & $76.21 \pm 20.55$ & 0.400 \\
\hline $\mathrm{PaCO}_{2}(\mathrm{mmHg})$ & $49.42 \pm|3.2|$ & $37.54 \pm 4.77$ & 0.000 \\
\hline
\end{tabular}

Notes: Data are presented as mean \pm standard deviation, number $(n)$, or percentage. $P$-value $<0.05$ was considered statistically significant: data shown in bold.

Abbreviations: BMI, body mass index; CAT, COPD assessment test; COPD, chronic obstructive pulmonary disease; CRP, C-reactive protein; FE, frequent exacerbations; $\mathrm{FEV}_{1}$, forced expiratory volume in I second; $\mathrm{FEV}_{1} / \mathrm{FVC}$, the ratio of FEV, and forced vital capacity; iFE, infrequent exacerbations; mMRC, modified British Medical Research Council breathlessness measurement; NLR, neutrophil lymphocyte ratio in whole blood; $\mathrm{PaCO}_{2}$, arterial carbon dioxide pressure; $\mathrm{PaO}_{2}$, arterial oxygen pressure.

emphysema and ACOS phenotypes, and other characteristics in subjects with FE did not differ from those in subjects with iFE (Table 1).

\section{Characteristics of the $\mathrm{CB}$ phenotype in COPD patients with FE}

As indicated in Table 2, CB phenotype COPD subjects with FE were significantly older than subjects with iFE $(P=0.003)$. BMI, $\mathrm{FEV}_{1} \%$ predicted, $\mathrm{FEV}_{1} / \mathrm{FVC}(\%), \mathrm{CAT}$, mMRC, emphysema scores and $\mathrm{PaCO}_{2}$ in $\mathrm{CB}$ phenotype subjects with FE shared significant differences with those in subjects with iFE. By multivariate analysis, we found that $\mathrm{FEV}_{1} \%$ predicted $(\mathrm{OR}=0.899, P=0.044)$ and $\mathrm{PaCO}_{2}$ $(\mathrm{OR}=1.215, P=0.017)$ were two independent risk factors for $\mathrm{CB}$ phenotype subjects with FE (Table 3).

Table 3 Independent risk factors for FE in COPD patients with chronic bronchitis phenotype by multivariate analysis

\begin{tabular}{llll}
\hline Variables & OR & $95 \% \mathbf{C l}$ & $P$-value \\
\hline $\mathrm{FEV}_{1}$ & 0.899 & $0.81-0.997$ & 0.044 \\
$\mathrm{PaCO}_{2}$ & 1.215 & $1.035-1.426$ & 0.017 \\
\hline
\end{tabular}

Note: $P$-value $<0.05$ was considered statistically significant.

Abbreviations: $\mathrm{Cl}$, confidence interval; COPD, chronic obstructive pulmonary disease; $\mathrm{FE}$, frequent exacerbations; $\mathrm{FEV}_{1}$, forced expiratory volume in I second; $\mathrm{OR}$, odds ratios; $\mathrm{PaCO}_{2}$, arterial carbon dioxide pressure. 
Table 4 Characteristics of emphysema phenotype in COPD patients with FE vs iFE

\begin{tabular}{|c|c|c|c|}
\hline Variables & $\begin{array}{l}\text { Subjects } \\
\text { with FE }\end{array}$ & $\begin{array}{l}\text { Subjects } \\
\text { with iFE }\end{array}$ & $P$-value \\
\hline Total subjects (N) & 20 & 38 & \\
\hline Male (n) & 16 & 32 & 0.475 \\
\hline Age (years) & $74 \pm 6.6$ & $67.5 \pm 10.16$ & 0.012 \\
\hline History of COPD (years) & $19.85 \pm 9.05$ & $10.66 \pm 7.28$ & 0.000 \\
\hline Smoking (pack $\times$ years) & $39.08 \pm 15.91$ & $36.76 \pm 18.07$ & 0.631 \\
\hline BMI $\left(\mathrm{kg} / \mathrm{m}^{2}\right)$ & $21.66 \pm 4.95$ & $20.87 \pm 2.78$ & 0.515 \\
\hline $\mathrm{FEV}_{1}$ (\% predicted) & $37.71 \pm 12.06$ & $44.07 \pm 16.83$ & 0.140 \\
\hline $\mathrm{FEV}_{1} / \mathrm{FVC}(\%)$ & $50.5 \pm 10.99$ & $58.45 \pm 9.32$ & 0.005 \\
\hline CAT score & $31.1 \pm 1.71$ & $23.87 \pm 5.98$ & 0.000 \\
\hline $\mathrm{mMRC}$ & $3.35 \pm 0.49$ & $2.16 \pm 0.79$ & 0.000 \\
\hline Emphysema score & $2.75 \pm I .12$ & $2.87 \pm 0.88$ & 0.658 \\
\hline Bronchial thickening score & $1.43 \pm 0.68$ & I. $19 \pm 0.4$ & 0.151 \\
\hline Leukocytes $\left(\times 10^{9}\right)$ & $6.76 \pm 2.24$ & $7.16 \pm 2.4$ & 0.545 \\
\hline NLR & $7.36 \pm 10.32$ & $5.63 \pm 4.81$ & 0.387 \\
\hline $\mathrm{CRP}(\mathrm{mg} / \mathrm{L})$ & $63.6 \pm 83.56$ & $47.64 \pm 79.44$ & 0.547 \\
\hline $\mathrm{pH}$ value & $7.4 I \pm 0.06$ & $7.42 \pm 0.05$ & 0.504 \\
\hline $\mathrm{PaO}_{2}(\mathrm{mmHg})$ & $87.95 \pm 20.97$ & $79.57 \pm 22.79$ & 0.245 \\
\hline $\mathrm{PaCO}_{2}(\mathrm{mmHg})$ & $43.87 \pm 10.86$ & $44.69 \pm 10.71$ & 0.812 \\
\hline
\end{tabular}

Notes: Data are indicated as mean \pm standard deviation, number $(n)$, or percentage. $P$-value $<0.05$ was considered statistically significant: data shown in bold.

Abbreviations: BMI, body mass index; CAT, COPD assessment test; COPD, chronic obstructive pulmonary disease; CRP, C-reactive protein; FE, frequent exacerbations; $\mathrm{FEV}_{1}$, forced expiratory volume in I second; $\mathrm{FEV}_{1} / \mathrm{FVC}$, the ratio of FEV, and forced vital capacity; iFE, infrequent exacerbations; mMRC, modified British Medical Research Council breathlessness measurement; NLR, neutrophil lymphocyte ratio in whole blood; $\mathrm{PaCO}_{2}$, arterial carbon dioxide pressure; $\mathrm{PaO}_{2}$, arterial oxygen pressure.

\section{Characteristics of the emphysema phenotype in COPD patients with FE}

As shown in Table 4, the age of EM phenotype subjects with $\mathrm{FE}$ was greater than subjects with iFE $(P=0.012)$. A longer history of COPD was observed in EM phenotype subjects with FE than in subjects with iFE. Similar to CB phenotype subjects, lower $\mathrm{FEV}_{1} / \mathrm{FVC}(\%)$ and higher CAT and mMRC scores were found in EM phenotype subjects with FE. However, there was no statistical difference in other variables, including BMI, $\mathrm{FEV}_{1} \%$ predicted and arterial blood $\mathrm{PaCO}_{2}$. Using multivariate analysis, CAT (OR $=2.601, P=0.001$ ) proved to be an independent risk factor for FE in COPD patients with the EM phenotype (Table 5).

Table 5 Independent risk factor for FE in COPD patients with emphysema phenotype by multivariate analysis

\begin{tabular}{llll}
\hline Variable & OR & $95 \% \mathbf{C l}$ & $P$-value \\
\hline CAT & 2.601 & $1.442-4.691$ & 0.001 \\
\hline
\end{tabular}

Note: $P$-value $<0.05$ was considered statistically significant.

Abbreviations: CAT, COPD assessment test; $\mathrm{Cl}$, confidence interval; COPD, chronic obstructive pulmonary disease; $\mathrm{FE}$, frequent exacerbations; $\mathrm{OR}$, odds ratio.
Table 6 Comparison of characteristics of ACOS phenotype in COPD patients with FE vs iFE

\begin{tabular}{|c|c|c|c|}
\hline Variables & $\begin{array}{l}\text { Subjects } \\
\text { with FE }\end{array}$ & $\begin{array}{l}\text { Subjects } \\
\text { with ifE }\end{array}$ & $P$-value \\
\hline Total subjects $(\mathrm{N})$ & 10 & 17 & \\
\hline Male (n) & 7 & 13 & 1.000 \\
\hline Age (years) & $65.6 \pm 12.77$ & $68.7 I \pm 10.05$ & 0.489 \\
\hline History of COPD (years) & $10.4 \pm 5.72$ & $9.76 \pm 6.57$ & 0.802 \\
\hline Smoking (pack $\times$ years) & $50.5 \pm 34.19$ & $33.79 \pm 12.64$ & 0.167 \\
\hline BMI $\left(\mathrm{kg} / \mathrm{m}^{2}\right)$ & $20.24 \pm 4.06$ & $21.24 \pm 3.57$ & 0.509 \\
\hline $\mathrm{FEV}_{1}$ (\% predicted) & $57.88 \pm 26.46$ & $55.32 \pm 16.03$ & 0.786 \\
\hline $\mathrm{FEV}_{\mathrm{I}} / \mathrm{FVC}(\%)$ & $49.81 \pm 10.91$ & $56.59 \pm 8.16$ & 0.077 \\
\hline CAT score & $26.8 \pm 5.47$ & $24.12 \pm 6.0$ & 0.258 \\
\hline $\mathrm{mMRC}$ & $2.5 \pm 0.97$ & $2.06 \pm 1.03$ & 0.283 \\
\hline Emphysema score & $2.4 \pm 1.43$ & $2.35 \pm 1.62$ & 0.940 \\
\hline Bronchial thickening score & $0.7 \pm 0.67$ & $0.59 \pm 0.62$ & 0.665 \\
\hline Leukocyte $\left(\times 10^{9}\right)$ & $6.5 I \pm 2.03$ & $8.13 \pm 3.07$ & 0.151 \\
\hline NLR & $4.9 \pm 3.17$ & $4.89 \pm 3.26$ & 0.993 \\
\hline $\mathrm{CRP}(\mathrm{mg} / \mathrm{L})$ & $24.36 \pm 29.71$ & $30.09 \pm 22.99$ & 0.821 \\
\hline $\mathrm{pH}$ value & $7.4 \pm 0.03$ & $7.42 \pm 0.03$ & 0.032 \\
\hline $\mathrm{PaO}_{2}(\mathrm{mmHg})$ & $94.84 \pm 29.0$ & $78.83 \pm 15.35$ & 0.103 \\
\hline $\mathrm{PaCO}_{2}(\mathrm{mmHg})$ & $38.39 \pm 9.53$ & $39.14 \pm 6.65$ & 0.829 \\
\hline
\end{tabular}

Notes: Data are indicated as mean \pm standard deviation, number $(\mathrm{n})$, or percentage. $P$-value $<0.05$ was considered statistically significant: data shown in bold.

Abbreviations: ACOS, asthma-COPD overlap syndrome; BMI, body mass index; CAT, COPD assessment test; COPD, chronic obstructive pulmonary disease; CRP, $\mathrm{C}$-reactive protein; $\mathrm{FE}$, frequent exacerbations; $\mathrm{FEV}_{1}$, forced expiratory volume in I second; $F E V, F F C$, the ratio of FEV and forced vital capacity; iFE, infrequent exacerbations; mMRC, modified British Medical Research Council breathlessness measurement; NLR, neutrophil lymphocyte ratio in whole blood; $\mathrm{PaCO}_{2}$, arterial carbon dioxide pressure; $\mathrm{PaO}_{2}$, arterial oxygen pressure.

\section{Characteristics of the ACOS phenotype in COPD patients with FE}

As shown in Table 6, arterial $\mathrm{pH}$ value was somewhat lower in the ACOS phenotype of COPD with FE than in the iFE subgroup ( $7.40 \pm 0.03$ vs $7.42 \pm 0.03 ; P=0.032$ ). However, there were no statistically significant differences in other characteristics between ACOS phenotype COPD subjects with FE and subjects with iFE.

\section{Discussion}

In line with previous reports, ${ }^{4,18-22}$ we revealed that COPD patients with FE showed significantly older age, longer history of disease, greater smoking index, worse lung function $\left(\mathrm{FEV}_{1} \%\right.$ predicted, $\mathrm{FEV}_{1} / \mathrm{FVC} \%$ ), higher $\mathrm{CAT}$, $\mathrm{mMRC}$ and bronchial thickening score, $\mathrm{PaCO}_{2}$ and more comorbidities (coronary heart disease and diabetes) than COPD patients with iFE. Higher bronchial thickening score is also associated with COPD patients with FE. ${ }^{20,23}$

Previous studies suggested that NLR (examining together the influences of neutrophilia and lymphopenia) reflected systemic inflammatory status in COPD, which was one of the independent predictors of future exacerbations. ${ }^{24,25}$ However, we found that NLR did not associate with FE in COPD in our study. 
Compared to $\mathrm{CB}$ phenotype COPD subjects with iFE, clinical characteristics of subjects with FE were older age, lower BMI, more severe airway obstruction (lower $\mathrm{FEV}_{1} \%$ predicted, $\mathrm{FEV}_{1} / \mathrm{FVC}$ ), increases of $\mathrm{CAT}$ and $\mathrm{mMRC}$ score, elevated $\mathrm{PaCO}_{2}$ in arterial blood and higher emphysema scores, compared to subjects with iFE. Low BMI is recognized as a marker for predicting future exacerbations among patients with COPD. ${ }^{26,27}$ Mucus hypersecretion in CB subjects causes distal airway collapse and air trapping, leading to increased residual volume and hyperinflation-emphysema. The ECLIPSE study has identified emphysema as a strong predictor for physiological decline in patients with COPD. ${ }^{1}$ We found that $\mathrm{FEV}_{1} \%$ predicted and $\mathrm{PaCO}_{2}$ were two independent risk factors for $\mathrm{CB}$ phenotype COPD presenting with $\mathrm{FE}$. The association between $\mathrm{FEV}_{1} \%$ predicted and $\mathrm{CB}$ phenotype with $\mathrm{FE}$ has been well documented. ${ }^{28,29} \mathrm{CB}$ phenotype COPD patients with FE present with increased sputum production and bronchial mucosal edema leading to bronchial obstruction, decreased pulmonary ventilation and, consequently, increased arterial $\mathrm{PaCO}_{2} \cdot{ }^{30}$ Similar to the $\mathrm{CB}$ phenotype, FE patients with EM phenotype also were older, had a longer history of COPD, lower $\mathrm{FEV}_{1} / \mathrm{FVC}(\%)$, higher $\mathrm{CAT}$ and mMRC scores, compared to iFE subjects. Consistent with previous reports, $\mathrm{FEV}_{1} \%$ predicted in $\mathrm{EM}$ subjects with $\mathrm{FE}$ did not differ from iFE subjects, supporting that $\mathrm{FEV}_{1} \%$ predicted is a poor clinical predictor for FE. ${ }^{31}$ Indeed, a group of COPD patients with high $\mathrm{FEV}_{1} \%$ predicted commonly experience FE. ${ }^{32}$ Clearly, $\mathrm{FEV}_{1} \%$ predicted does not reflect the complexity of COPD, nor alone adequately assess treatment effect in patients with COPD. ${ }^{33,34}$ Thus, other factors in COPD patients, such as clinical variables, biological indicators and history of exacerbations, need to be evaluated. The associations between emphysema and FE in patients with COPD were inconsistent in previous publications, though we pointed out that emphysema score shared no difference between FE and iFE. ${ }^{20,23,35}$ Using multivariate analysis, we identified CAT score was an independent risk factor for FE in EM phenotype COPD. This is consistent with previous studies. ${ }^{36,37}$ The CAT score - which includes 8 questions with scores ranging from 0 to 40 for evaluating symptoms of patients with COPD - is able to more comprehensively capture the impact of COPD symptoms on the daily life and physical and mental health of patients. Clinical symptoms of COPD may provide important information, which should be comprehensively considered for predicting future COPD exacerbations. ${ }^{38,39}$

Unlike in CB or EM phenotypes, clinical characteristics in ACOS phenotype subjects with FE were not particularly distinguishable from those with iFE. Other factors relating to the asthma, such as atopy, environmental exposures and airway inflammation, may help to identify contributors to FE in the ACOS phenotype.

Some limitations exist in the present study. First, this was a retrospective study and the sample size was small. Second, other phenotypes or endotypes were not appraised in this study. Finally, the underlying mechanisms resulting in differences between the FE risks among the phenotypes were not clarified.

\section{Conclusion}

Our study identified differential clinical characteristics in the CB, EM and ACOS phenotypes of COPD patients with FE, compared with patients with iFE. We demonstrated related risk factors for the existence of $\mathrm{FE}$ in patients with $\mathrm{CB}$ or EM phenotype. An understanding of FE in ACOS phenotype patients will require more investigation.

\section{Acknowledgments}

Support for this work has been awarded to Chen Xingwu by the Anhui Provincial Natural Science Foundation (1608085 MH192) and the Scientific Research Foundation of Yijishan Hospital of Wannan Medical College for the Introduction of Talent (YR201401), and to Cheng Yusheng by the Anhui Provincial Key projects of Natural Science Foundation for Colleges and Universities (KJ2017A264) and Key projects of Wannan Medical College (KY22340150).

\section{Author contributions}

All authors contributed toward data analysis, drafting and critically revising the paper and agree to be accountable for all aspects of the work.

\section{Disclosure}

The authors report no conflicts of interest in this work.

\section{References}

1. Vestbo J, Agusti A, Wouters EF, et al. Should we view chronic obstructive pulmonary disease differently after ECLIPSE? A clinical perspective from the study team. Am J Respir Crit Care Med. 2014;189(9): 1022-1030.

2. Allen-Ramey FC, Gupta S, DiBonaventura MD. Patient characteristics, treatment patterns, and health outcomes among COPD phenotypes. Int J Chron Obstruct Pulmon Dis. 2012;7:779-787.

3. de Oca MM, Halbert RJ, Lopez MV, et al. The chronic bronchitis phenotype in subjects with and without COPD: the PLATINO study. Eur Respir J. 2012;40:28-36.

4. Oh YM, Sheen SS, Park JH, et al. Emphysematous phenotype is an independent predictor for frequent exacerbation of COPD. Int J Tuberc Lung Dis. 2014;18(12):1407-1414.

5. Gelb AF, Christenson SA, Nadel JA. Understanding the pathophysiology of the asthma-chronic obstructive pulmonary disease overlap syndrome. Curr Opin Pulm Med. 2016;22(2):100-105.

6. Izquierdo-Alonso JL, Rodriguez-Gonzalezmoro JM, de Lucas-Ramos P, et al. Prevalence and characteristics of three clinical phenotypes of chronic obstructive pulmonary disease (COPD). Respir Med. 2013; 107(5):724-731. 
7. Elbehairy AF, Raghavan N, Cheng S, et al. Physiologic characterization of the chronic bronchitis phenotype in GOLD grade IB COPD. Chest. 2015;147(5):1235-1245.

8. Caillaud D, ChanezP, Escamilla R, et al. Asthma-COPD overlap syndrome (ACOS) vs 'pure' COPD: a distinct phenotype? Allergy. 2017;72(1): $137-145$.

9. Miravitlles M, Calle M, Soler-Cataluna JJ. Clinical phenotypes of COPD: identification, definition and implications for guidelines. Arch Bronconeumol. 2012;48(3):86-98.

10. Hurst JR, Vestbo J, Anzueto A, et al. Susceptibility to exacerbation in chronic obstructive pulmonary disease. $N$ Engl J Med. 2010;363(12): $1128-1138$.

11. Blasi F, Neri L, Centanni S, et al. Clinical characterization and treatment patterns for the frequent exacerbator phenotype in chronic obstructive pulmonary disease with severe or very severe airflow limitation. COPD. 2017;14(1):15-22.

12. Miravitlles M, Soler-Cataluna JJ, Calle M, et al. Treatment of COPD by clinical phenotypes: putting old evidence into clinical practice. Eur Respir J. 2013;41(6):1252-1256.

13. Wan ES, DeMeo DL, Hersh CP, et al. Clinical predictors of frequent exacerbations in subjects with severe chronic obstructive pulmonary disease (COPD). Respir Med. 2011;105(4):588-594.

14. Soler-Cataluna JJ, Rodriguez-Roisin R. Frequent chronic obstructive pulmonary disease exacerbators: how much real, how much fictitious? COPD. 2010;7(4):276-284.

15. Soler-Cataluna JJ, Cosio B, Izquierdo JL, et al. Consensus document on the overlap phenotype COPD-asthma in COPD. Arch Bronconeumol. 2012;48(9):331-337.

16. Chae EJ, Seo JB, Song JW, et al. Slope of emphysema index: an objective descriptor of regional heterogeneity of emphysema and an independent determinant of pulmonary function. AJR Am J Roentgenol. 2010;194(3):W248-W255.

17. da Silva SM, Paschoal IA, De Capitani EM, et al. COPD phenotypes on computed tomography and its correlation with selected lung function variables in severe patients. Int J Chron Obstruct Pulmon Dis. 2016;11: 503-513.

18. McGarvey L, Lee AJ, Roberts J, et al. Characterisation of the frequent exacerbator phenotype in COPD patients in a large UK primary care population. Respir Med. 2015;109(2):228-237.

19. Aziz ZA, Wells AU, Desai SR, et al. Functional impairment in emphysema: contribution of airway abnormalities and distribution of parenchymal disease. AJR Am J Roentgenol. 2005;185(6): $1509-1515$.

20. Han MK, Kazerooni EA, Lynch DA, et al. Chronic obstructive pulmonary disease exacerbations in the COPDGene study: associated radiologic phenotypes. Radiology. 2011;261(1):274-282.

21. Donaldson GC, Hurst JR, Smith CJ, et al. Increased risk of myocardial infarction and stroke following exacerbation of COPD. Chest. 2010; 137(5):1091-1097.

22. Divo M, Cote C, de Torres JP, et al. Comorbidities and risk of mortality in patients with chronic obstructive pulmonary disease. Am J Respir Crit Care Med. 2012;186(2):155-161.

23. Han MK, Bartholmai B, Liu LX, et al. Clinical significance of radiologic characterizations in COPD. COPD. 2009;6(6):459-467.
24. Lee H, Um SJ, Kim YS, et al. Association of the neutrophil-to-lymphocyte ratio with lung function and exacerbations in patients with chronic obstructive pulmonary disease. PLoS One. 2016;11(6):e0156511.

25. Gunay E, Sarinc Ulasli S, Akar O, et al. Neutrophil-to-lymphocyte ratio in chronic obstructive pulmonary disease: a retrospective study. Inflammation. 2014;37(2):374-380.

26. Motegi T, Jones RC, Ishii T, et al. A comparison of three multidimensional indices of COPD severity as predictors of future exacerbations. Int J Chron Obstruct Pulmon Dis. 2013;8:259-271.

27. Alexopoulos EC, Malli F, Mitsiki E, et al. Frequency and risk factors of COPD exacerbations and hospitalizations: a nationwide study in Greece (Greek Obstructive Lung Disease Epidemiology and health ecoNomics: GOLDEN study). Int J Chron Obstruct Pulmon Dis. 2015;10: 2665-2674.

28. Sundh J, Johansson G, Larsson K, et al. The phenotype of concurrent chronic bronchitis and frequent exacerbations in patients with severe COPD attending Swedish secondary care units. Int J Chron Obstruct Pulmon Dis. 2015;10:2327-2334.

29. Donaldson GC, Mullerova H, Locantore N, et al. Factors associated with change in exacerbation frequency in COPD. Respir Res. 2013; 14(1):79.

30. Bates ML, Farrell ET, Eldridge MW. Abnormal ventilatory responses in adults born prematurely. $N$ Engl J Med. 2014;370(6):584-585.

31. Kirby SE, Dennis SM, Jayasinghe UW, et al. Patient related factors in frequent readmissions: the influence of condition, access to services and patient choice. BMC Health Serv Res. 2010;10(1):216.

32. Thomsen M, Ingebrigtsen TS, Marott JL, et al. Inflammatory biomarkers and exacerbations in chronic obstructive pulmonary disease. JAMA. 2013;309(22):2353-2361.

33. Bhavani S, Tsai CL, Perusich S, et al. Clinical and immunological factors in emphysema progression. Five-year prospective longitudinal exacerbation study of chronic obstructive pulmonary disease (LESCOPD). Am J Respir Crit Care Med. 2015;192(10):1171-1178.

34. Hesselbacher SE, Ross R, Schabath MB, et al. Cross-sectional analysis of the utility of pulmonary function tests in predicting emphysema in eversmokers. Int J Environ Res Public Health. 2011;8(5):1324-1340.

35. Tulek B, Kivrak AS, Ozbek S, et al. Phenotyping of chronic obstructive pulmonary disease using the modified Bhalla scoring system for highresolution computed tomography. Can Respir J. 2013;20(2):91-96.

36. Feliz-Rodriguez D, Zudaire S, Carpio C, et al. Evolution of the COPD Assessment Test score during chronic obstructive pulmonary disease exacerbations: determinants and prognostic value. Can Respir J. 2013; 20(5):e92-e97.

37. Miravitlles M, Garcia-Sidro P, Fernandez-Nistal A, et al. The chronic obstructive pulmonary disease assessment test improves the predictive value of previous exacerbations for poor outcomes in COPD. Int J Chron Obstruct Pulmon Dis. 2015;10:2571-2579.

38. Kerkhof M, Freeman D, Jones R, et al. Predicting frequent COPD exacerbations using primary care data. Int J Chron Obstruct Pulmon Dis. 2015;10:2439-2450.

39. Pasquale MK, Xu Y, Baker CL, et al. COPD exacerbations associated with the modified Medical Research Council scale and COPD assessment test among Humana Medicare members. Int J Chron Obstruct Pulmon Dis. 2016;11(1):111-121.
International Journal of COPD

\section{Publish your work in this journal}

The International Journal of COPD is an international, peer-reviewed journal of therapeutics and pharmacology focusing on concise rapid reporting of clinical studies and reviews in COPD. Special focus is given to the pathophysiological processes underlying the disease, intervention programs, patient focused education, and self management protocols.

\section{Dovepress}

This journal is indexed on PubMed Central, MedLine and CAS. The manuscript management system is completely online and includes a very quick and fair peer-review system, which is all easy to use. Visit $\mathrm{http}: / / \mathrm{www}$. dovepress.com/testimonials.php to read real quotes from published authors. 